\title{
Immune Lysis of Normal Human and Paroxysmal Noc- turnal Hemoglobinuria (PNH) Red Blood Cells. II. The Role of Complement Components in the In- creased Sensitivity of PNH Red Cells to Immune Lysis*
}

\author{
Wendell F. Rosse † and J. V. Dacie
}

(From the Department of Haematology, Postgraduate Medical School, London, England)

In a previous paper (1) we demonstrated quantitatively the increased susceptibility of the red cells of patients with paroxysmal nocturnal hemoglobinuria (PNH) to lysis by specific antibody and complement. PNH cells were found to consist of two populations of red cells, one which was about 25 times as sensitive to complement lysis as normal cells, the other only slightly more sensitive than normal cells. The purpose of the present study is to elucidate the relative roles of complement $\left(C^{\prime}\right)$ and antibody in accounting for this increased sensitivity.

The increased susceptibility of PNH cells to lysis by complement and antibody has been attributed to the ability of these cells to take up a greater amount of antibody, as suggested by higher agglutination titers when these cells were used (2). The present experiments indicate that increased antibody uptake does not play a major role in the increased sensitivity of $\mathrm{PNH}$ cells to complement lysis. The increased sensitivity appears to be due, then, to a greater susceptibility of the cell to the action of $\mathrm{C}^{\prime}$, or to a greater efficiency of the reactions of $C^{\prime}$ once the sequence of reactions has been begun by antibody.

Differences in efficiency of $\mathrm{C}^{\prime}$ activity theoretically could occur in any of the complex reac-

* Submitted for publication May 25, 1965 ; accepted January 20, 1966.

This work was presented in part at the $X$ Congress of the International Society of Haematology, Stockholm, Sweden, August 29 to September 4, 1964.

$\dagger$ Address requests for reprints to Dr. Wendell F. Rosse, Dept. of Medicine, Duke University Medical Center, Durham, N. C.

Work performed during tenure as a visiting research fellow from the Metabolism Service, National Cancer Institute, Bethesda, Md. tions of the components of complement (designated $C^{\prime} 1, C^{\prime} 2, C^{\prime} 3$, or $\left.C^{\prime} 4\right)$. These reactions are presently understood to occur as follows (3):

$\mathrm{E}$ (red cell) $+\mathrm{A}$ (antibody) $\longrightarrow \mathrm{EA}$.

$\mathrm{EA}+\mathrm{C}^{\prime} 1 \stackrel{\mathrm{Ca}^{++}}{\longrightarrow} \mathrm{EAC}^{\prime} \longrightarrow \mathrm{EAC}_{1 \mathrm{a}} \longrightarrow$

(addition and activation of $\mathrm{C}^{\prime} 1$ ).

$\mathrm{EAC}_{1 \mathrm{a}}^{\prime}+\mathrm{C}^{\prime} 4 \longrightarrow \mathrm{EAC}_{1 \mathrm{a}, 4}^{\prime}$

(addition of $\mathrm{C}^{\prime} 4$ ).

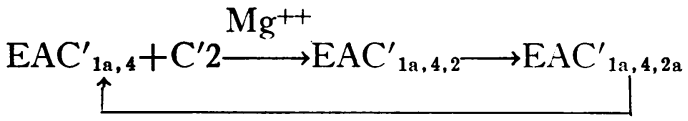

(addition and activation of $\mathrm{C}^{\prime} 2$ ). The return of $\mathrm{EAC}^{\prime}{ }_{1 \mathrm{a}, 4,2 \mathrm{a}}$ to $\mathrm{EAC}^{\prime}{ }_{1 \mathrm{a}, 4}$ is a degradation reaction the rate of which is heat dependent (5).

$\mathrm{EAC}_{1 \mathrm{a}, 4,2 \mathrm{a}}^{\prime}+\mathrm{C}^{\prime} 3$ components ${ }^{1} \longrightarrow$ $\mathrm{EAC}^{\prime}{ }_{1 \mathrm{a}, 4,2 \mathrm{a}, 3}$ or $\mathrm{E}_{\mathrm{p}}^{*}\left(\mathrm{E}_{\mathrm{p}}^{*}\right.$ is the precursor form of red cells irreversibly damaged by the action of complement).

$\mathrm{E}_{\mathrm{p}}^{*} \stackrel{\text { heat }}{\longrightarrow} \mathrm{E}_{\mathrm{a}}^{*}$ (activated form). $\mathrm{E}_{\mathrm{p}}^{*}$ and $E^{*}$ will not lyse unless the concentration of EDTA is reduced below 0.09 mole per L (7). [7] $\mathrm{E}^{*}{ }_{\mathrm{a}} \longrightarrow \mathrm{E}^{*}{ }_{0}$. $\mathrm{E}^{*}{ }_{0}$ will not lyse in the presence of $25 \% \mathrm{wt} /$ vol serum albumin (8).

$\mathrm{E}^{*}{ }_{0} \longrightarrow$ ghosts and hemoglobin.

In the course of this complex series of reactions, apparent differences in the efficiency of complement could occur due to differences in the cells

${ }^{1} C^{\prime} 3$ probably consists of at least three components. The identity of these, their reactions, and their nomenclature remain somewhat in doubt (6). 
upon which the reactions take place. The results of the present investigations of some of the reactions of $\mathrm{C}^{\prime}$ components indicate that the efficiency of complement component reactions in the early reactions of the sequence are the same on normal and PNH cells and that the greater efficiency of complement in lysing $\mathrm{PNH}$ cells must, therefore, be due to differences in the final reactions of the sequence.

\section{Methods}

Red cells. Red blood cells were collected, preserved, and prepared for use in the manner outlined in the previous paper (1). The standard suspension containing approximately $2 \times 10^{8}$ cells per $\mathrm{ml}$ was prepared in the same manner as outlined.

Antibody. The anti-I antibody of exceptional hemolytic potency used in the previous work (1) was used throughout.

Complement. Complement of human and guinea pig origin was collected, absorbed, stored, and prepared for use as in the previous paper (1).

Buffers. Isotonic barbital (Veronal)-saline buffer (VSB), made as outlined previously (3), was used throughout unless otherwise stated. The stock solution was diluted and calcium chloride $(0.00015 \mathrm{M})$, magnesium chloride $(0.0005 \mathrm{M})$, and $0.1 \%$ gelatin were added the day of use.

$E D T A$. The disodium salt of ethylenediaminetetraacetic acid was prepared and stored as an isosmotic $0.09 \mathrm{M}$ solution, the $\mathrm{pH}$ of which was adjusted to 7.5 with concentrated $\mathrm{NaOH}$. Dilute solutions of this were made with isotonic VSB lacking calcium and magnesium.

Sucrose. Isotonic sucrose buffer was made by dissolving $48.6 \mathrm{~g}$ of sucrose and $0.5095 \mathrm{~g}$ of $\mathrm{Na} \mathrm{5,5-diethylbarbi-}$ turic acid (sodium barbital) in $500 \mathrm{ml}$ of distilled water. The $\mathrm{pH}$ was adjusted to 7.4 with concentrated $\mathrm{HCl}$. Calcium and magnesium ions and gelatin were added to the same concentrations as in VSB at the time of use. Solutions of reduced ionic strength were prepared by mixing appropriate amounts of isotonic sucrose buffer and isotonic VSB (9).

Optimal dilution of antibody. The dilution of antibody which, used in the presence of a fixed quantity of $\mathrm{C}^{\prime}$, will lyse the greatest number of normal cells, was determined as outlined in the previous paper (1). This was 1 in 40 dilution for the anti-I antibody used for most experiments.

Complement-sensitivity titration. The estimate of the sensitivity of cells to complement lysis was performed as outlined in the previous paper (1).

Hemolytic antibody titration. The hemolytic antibody titer of solutions containing anti-I antibody was determined by appropriate modification of Mayer's technique (3) for the determination of the hemolytic antibody titer of rabbit antisheep red cell antiserum. The red cells of patients with $\mathrm{PNH}$ were used; the proportion of sensitive cells was estimated by the complement lysis sensitivity test or by a preliminary antibody titration involving a wide range of antibody dilutions. After preliminary experiments, a basic dilution and three doubling dilutions of antibody were selected to give, insofar as possible, partial lysis of the sensitive cells in all tubes. Five-tenths $\mathrm{ml}$ of $\mathrm{PNH}$ cells in a concentration half that of the standard suspension (i.e., $1.1 \times 10^{8}$ cells per $\mathrm{ml}$ ) was added at $0^{\circ} \mathrm{C}$ to $0.5-\mathrm{ml}$ volumes of the antibody in an initial and three doubling dilutions. Exactly 1 minute later, $0.25 \mathrm{ml}$ of ice-cold whole human serum was added as a source of complement. After incubating for exactly 12 minutes at $0^{\circ} \mathrm{C}$, the tubes were transferred to the $37^{\circ} \mathrm{C}$ water bath ; exactly 15 minutes later $2.5 \mathrm{ml}$ of cold $0.01 \mathrm{M}$ EDTA buffer was added, and the tubes were placed at $0^{\circ} \mathrm{C}$ and centrifuged in the cold. When multiple samples were assayed, pipettings of each series of four tubes were spaced at intervals of 1 minute so that the time relationship could be maintained accurately. The hemolysis in each tube was determined, after centrifugation, in the spectrophotometer at a wavelength of $541 \mathrm{~m} \mu$, and the fraction of the sensitive cells lysed $(y)$ was calculated. The Von Krogh equation was used to correct for the sigmoid shape of the curve. When the logarithm of $y /(1-y)$ was plotted against the logarithm of the relative dilution of antibody, a straight line resulted. The dilution at which the line intersected 1.0 represented the dilution producing $50 \%$ hemolysis under these conditions. Therefore, the unit of antibody was defined as the dilution of antiserum $0.5 \mathrm{ml}$ of which, in the presence of $0.25 \mathrm{ml}$ of human serum, lysed $50 \%$ of the sensitive cells in $0.5 \times 10^{8} \mathrm{PNH}$ red cells in 15 minutes after incubation for 12 minutes at $0^{\circ}$. The value obtained varied with the $\mathrm{PNH}$ cells used and hence was relative. In all comparable experiments described below, the hemolytic antibody titer was determined with the cells of the same $\mathrm{PNH}$ patient; in most cases, the proportion of sensitive cells was greater than $80 \%$.

Determination of the adsorption of antibody on red cells. The ability of the anti-I antibody used in these experiments to combine with various types of human red cells was tested by a modification of Mayer's inhibition assay (3). For each specimen of red cells to be tested standard suspensions containing $2 \times 10^{8}$ red cells per $\mathrm{ml}$ were prepared and diluted with isotonic VSB in doubling dilutions to 1 in 16 , (i.e., to $0.125 \times 10^{8}$ cells per $\mathrm{ml}$ ). One $\mathrm{ml}$ of each of these suspensions was mixed at $0^{\circ} \mathrm{C}$ with $1 \mathrm{ml}$ of an antibody solution containing 15 hemolytic units $\left(\mathrm{AbH}_{50}\right)$ per $\mathrm{ml}$, determined as outlined above. The cells and antibody were allowed to react for 30 minutes and were centrifuged at $0^{\circ} \mathrm{C}$. The hemolytic antibody titer of the supernatant fluid was determined as above, and the percentage of the original antibody remaining in the supernatant fluid after incubation was plotted against the number of red cells used in adsorption.

$C^{\prime} 1 a$ fixation and transfer test. The amount of purified first component of complement ( $\left.C^{\prime} 1 \mathrm{a}\right)$ fixed by anti-I antibody on normal and $\mathrm{PNH}$ cells was determined by the $\mathrm{C}^{\prime} 1 \mathrm{a}$ fixation and transfer test of Borsos and Rapp (10) as modified by Rosse, Borsos, and Rapp (11). One-tenth ml of a suspension of test cells in $60 \%$ isotonic sucrose- $40 \%$ VSB buffer containing $2.2 \times 10^{8}$ cells per ml was mixed with $0.1 \mathrm{ml}$ of a $1 / 100$ dilution of anti-I antibody in a 
siliconized tube at $0^{\circ} \mathrm{C}$. Three-tenths $\mathrm{ml}$ of functionally purified C'1a prepared from guinea pig serum by the method of Borsos and Rapp (12) was added and the mixture incubated for 30 minutes. The cells were washed with icecold $60 \%$ isotonic sucrose- $40 \%$ VSB buffer, transferred into a second set of tubes, and washed three more times with this buffer. They were suspended in $1 \mathrm{ml}$ of VSB, ninefold falling dilutions were made, and the amount of C'1a present was assayed according to the method of Borsos and Rapp (12).

The number of $C^{\prime} 1 \mathrm{a}$ molecules present per test cell was calculated from the following formula: $x=\left(2.2 \times 10^{8}\right.$ $\times z \times$ dilution of $\left.\mathrm{C}^{\prime} \mathrm{la} \times 10\right) /\left(2.2 \times 10^{7}\right)$, where $x=$ number of molecules of $C^{\prime} 1$ a per test red cell, $z=-\log _{e}$ $(1-y)$, and $y=$ percentage lysis of sheep cells used in assay of C'1a.

Determination of the amount of $C^{\prime}$ bound per unit antibody bound. For determination of the ratio of $\mathrm{C}^{\prime}$ fixed to amount of antibody adsorbed for $\mathrm{PNH}$ and normal cells, red cells in known numbers or washed red cell stromata prepared from known numbers of cells by gradual osmotic lysis were suspended in $2 \mathrm{ml}$ of isotonic VSB and were reacted with $1 \mathrm{ml}$ of a dilution of antiserum containing the anti-I antibody and $1 \mathrm{ml}$ of whole normal human serum as a source of $C^{\prime}$. This mixture was incubated for various periods of time at $0^{\circ}$ or $3^{\circ} \mathrm{C}$ and the cells or stroma removed by centrifugation at $18,000 \mathrm{rpm}$ for 30 minutes. The supernatant was then divided; one part was heated to $56^{\circ} \mathrm{C}$ for 30 minutes and assayed for hemolytic antibody activity by the assay described above. The other portion was assayed for $C^{\prime}$ content, by the sheep cell-rabbit antiserum system described by Mayer (3). Controls, which were treated in the same way, consisted of antibody alone, antibody and complement, complement alone, and complement with cells. The amount of antibody adsorbed by the cells or cell stromata was determined by difference as was the amount of $C^{\prime}$ fixed. The ratio of complement fixed to antibody adsorbed was calculated.

The degradation rate of $\mathrm{C}^{\prime} 2$ on cellular intermediates. To produce the cellular intermediate " $E A C_{1 a, 4,2 a}{ }^{2}, 2$ we incubated together equal volumes of a standard suspension of red cells in $60 \%$ isotonic sucrose- $40 \%$ VSB and whole human or guinea pig serum at exactly $0^{\circ} \mathrm{C}$ for periods of 10 to 60 minutes. The cells were then washed three times with $60 \%$ isotonic sucrose- $40 \%$ VSB at $0^{\circ} \mathrm{C}$ and suspended

\footnotetext{
${ }^{2}$ For the purposes of the present paper the notation "EAC' ${ }_{1 \mathrm{a}, 4,2 \mathrm{a}}$ " (or "SAC' ${ }_{1 \mathrm{a}, 4,2 \mathrm{a}}$ " where $\mathrm{S}$ indicates an antigen site) will be used when the presence of cellular intermediates containing components of $\mathrm{C}^{\prime} 3$ is not excluded by the preparative procedures. When this intermediate is made in such a way that $C^{\prime} 3$ components are functionally absent (e.g., EAC ${ }_{18,4}^{\prime}+$ purified $C^{\prime} 2$ ), the quotation marks will be omitted. Because the status, number, and nomenclature of $\mathrm{C}^{\prime} 3$ components are uncertain, no effort is made to distinguish among them. In the present paper, the presence of one or more but not all components of $\mathrm{C}^{\prime} 3$ on the intermediate $\mathrm{EAC}_{1 \mathrm{a}, 4,2 \mathrm{a}}$ will be indicated by the

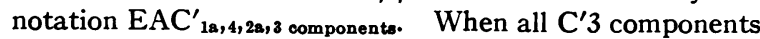
are present, the notation $\mathrm{EAC}_{1 \mathrm{a}, 4,2 \mathrm{a}, 3}$ or $\mathrm{E}^{*}$ will be used.
}

in a volume of the same buffer eight times the original volume of the cell suspension. The presence of cells in the

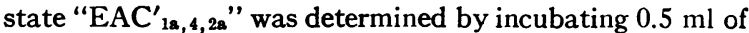
the final cell suspension with $0.5 \mathrm{ml}$ of normal human serum diluted 1 in 3 to 1 in 5 with $0.02 \mathrm{M}$ EDTA in VSB without $\mathrm{Mg}^{++}$or $\mathrm{Ca}^{++}\left(\mathrm{C}^{\prime}\right.$-EDTA $)$ at $37^{\circ} \mathrm{C}$ for 60 minutes. Controls consisted of the following: $0.5 \mathrm{ml}$ of $\mathrm{C}^{\prime}$-EDTA, 0.5 $\mathrm{ml}$ of cells treated with antibody and complement ("EAC' ${ }_{1 \mathrm{~s}, 4,2 \mathrm{~s}}$ ") $+0.5 \mathrm{ml}$ of $0.02 \mathrm{M}$ EDTA in VSB, $0.5 \mathrm{ml}$ of $C^{\prime}$-EDTA $+0.5 \mathrm{ml}$ of $60 \%$ isotonic sucrose buffer- $40 \%$ $\mathrm{VSB}$, and $0.5 \mathrm{ml}$ of "EAC' ${ }_{1 \mathrm{a}, 4,2 \mathrm{a}}$ " $+0.5 \mathrm{ml} 0.04 \%$ $\mathrm{NH}_{4} \mathrm{OH}$. At the end of the incubation the total volume of the mixtures was brought to 3.0 or $4.0 \mathrm{ml}$ with buffer, and the cells were removed by centrifugation. The amount of lysis was determined spectrophotometrically at a wavelength of $412 \mathrm{~m} \mu$ and the net lysis determined by subtraction of the appropriate control readings. The fraction lysed, $y$, was determined by dividing the corrected optical density by that of the completely lysed control. With one completed complement reaction assumed sufficient for the lysis of any one cell, the number of sites, $z$, per cell in the state "SAC' ${ }_{18,4,2 a}$ " that were capable of completing the complement sequence was calculated by the formula, $x=-\log _{e}(1-y)$, according to Rapp (6) and Borsos, Rapp, and Mayer (13).

To determine the rate of degradation of cells in the state "EAC' ${ }_{1 \mathrm{a}, 4,2 \mathrm{~s}}$ " to the state $\mathrm{EAC}^{\prime}{ }_{1 \mathrm{a}, 4}$ (i.e., to a state such that serum diluted in 0.03 M EDTA in VSB does not provide the components capable of bringing about lysis), we made cells in the state "EAC' ${ }_{1 \mathrm{a}, 4,2 \mathrm{a}}$ " as above and pipetted $0.5-\mathrm{ml}$ volumes into test tubes placed in an ice bath. The tubes were then placed at $37^{\circ} \mathrm{C}$, and 1 minute was allowed for the tubes to come to this temperature. Prewarmed human serum diluted 1 part in 5 in $0.02 \mathrm{M}$ EDTA in VSB was added at specific time intervals, and the tubes were incubated for a further 60 minutes after this addition. At the end of this incubation they were removed, diluted, and read, and the results were analyzed as above. The logarithm of the average number of sites per red cell in the state "SAC' ${ }_{1 \mathrm{a}, 4,2 \mathrm{a}}$ " (i.e., sites capable of completing the complement sequence in the presence of $0.02 \mathrm{M}$ EDTA) was plotted against the time of incubation before the addition of C'-EDTA. The lines best fitted by single exponential functions were determined by the least squares method.

To produce cellular intermediates $\mathrm{EAC}^{\prime}{ }_{1 \mathrm{a}, 4,2 \mathrm{a}}$ known to be lacking $\mathrm{C}^{\prime} 3$ components, we made "EAC' ${ }_{1 \mathrm{a}, 4,2 \mathrm{a}}$ " as above, using both normal and $\mathrm{PNH}$ cells and guinea pig serum as a source of $\mathrm{C}^{\prime}$ components. These cells were warmed for 120 minutes at $37^{\circ} \mathrm{C}$ and stored for 2 days at $0^{\circ} \mathrm{C}$; they were thus rendered incapable of being lysed by $C^{\prime}$-EDTA, i.e., they had decayed to the state EAC $_{18,4}^{\prime}$ Since $C^{\prime} 2$ is simultaneously added, activated, and destroyed at $\mathrm{SAC}_{1 \mathrm{a}, 4}^{\prime}$ sites at finite rates, there is an optimal time after the addition of purified $\mathrm{C}^{\prime} 2$ to cells in the state $\mathrm{EAC}^{\prime}{ }_{1 \mathrm{a}, 4}$ at which the maximal number of sites in the state EAC $_{1 \mathrm{a}, 4,2}$ may be formed. This time, $t_{\max }$, was determined for normal and $\mathrm{PNH}$ cells in the state EAC $^{\prime}{ }_{1 \mathrm{a}, 4}$ in a manner analogous to that used by Borsos and coworkers (13). Cells in the state $\mathrm{EAC}_{1 \mathrm{r}, 4}$ were washed with $60 \%$ isotonic sucrose $-40 \%$ VSB and suspended at 
$37^{\circ} \mathrm{C}$ in functionally purified guinea pig $\mathrm{C}^{\prime} 2^{3}$ diluted 1 in 20 in $60 \%$ isotonic sucrose- $40 \%$ VSB. At intervals of time, $0.5-\mathrm{ml}$ portions were removed and pipetted into 0.5 $\mathrm{ml}$ of guinea pig $\mathrm{C}^{\prime}$ diluted 1 in 10 in $0.01 \mathrm{M}$ EDTA in VSB. After 60 minutes' incubation, the total volume of the mixtures was brought up to $4.0 \mathrm{ml}$ and centrifuged. The amount of lysis was determined with the Unicam spectrophotometer at a wavelength of $412 \mathrm{~m} \mu$, and correction was made for spontaneous lysis and for complement color. The fraction of cells lysed was plotted against the time after addition of $C^{\prime} 2$ at which $C^{\prime}$-EDTA was added. The time at which the greatest degree of lysis occurred was determined by inspection.

To determine the rate of degradation of the intermediate EAC $_{1 \mathrm{a}, 4,2 \mathrm{a}}$, when the $\mathrm{C}^{\prime} 2$ was supplied in purified form, we made cells in the state EAC $_{1 \mathrm{a}, 4}$, as described above using guinea pig serum., These cells were then reacted with equal volumes of purified guinea pig $C^{\prime} 2$, diluted 1 in 20 in $60 \%$ isotonic sucrose $-40 \% \mathrm{VSB}$, at $37^{\circ} \mathrm{C}$ for the optimal time, determined as described above. They were then diluted fourfold with ice-cold $60 \%$ isotonic sucrose- $40 \%$ VSB, centrifuged at $0^{\circ} \mathrm{C}$, resuspended in the same buffer, and maintained at $0^{\circ} \mathrm{C}$. The rate of degradation of $\mathrm{EAC}^{\prime}{ }_{1 \mathrm{a}, 4,2 \mathrm{a}}$ was then determined as above.

\section{Results}

Sensitivity to complement lysis. The results of complement lysis sensitivity tests on normal red cells, papainized normal red cells, and PNH red cells reported in the previous paper are summarized in Table I. They indicate that papainized normal cells require somewhat less $\mathrm{C}^{\prime}$ than unpapainized normal cells for $50 \%$ lysis but that the sensitive population of PNH cells requires very much less $\mathrm{C}^{\prime}$ than either.

Adsorption of antibody. The results of the experiments on the adsorption of antibody by each of the three types of cells-normal, papainized normal, and PNH-are illustrated in Figure 1. The relative ability of papainized and $\mathrm{PNH}$

\section{TABLE I}

Complement lysis sensitivity titers of normal, $P N H$, and papainized normal cells as determined with human $C^{\prime}$ and ant $i-I$ antibody $(1)$ *

\begin{tabular}{lccc}
\hline \multicolumn{1}{c}{ Type of cells } & $\begin{array}{c}\text { No. of } \\
\text { determin- } \\
\text { ations }\end{array}$ & $\begin{array}{c}\text { C' lysis } \\
\text { titer sensi- } \\
\text { tivity }\end{array}$ & $\begin{array}{c}\text { Range of } \\
\text { observed } \\
\text { values }\end{array}$ \\
\hline Normal & 10 & 1.18 & $0.66-1.55$ \\
Papainized normal & 5 & 1.88 & $1.66-2.16$ \\
PNH & 10 & 2.7 & $1.2-5.0$ \\
"Insensitive" cells & & 30.1 & $20-47$ \\
"Sensitive" cells & & & \\
\hline
\end{tabular}

* $\mathrm{PNH}=$ paroxysmal nocturnal hemoglobinuria $; \mathrm{C}^{\prime}=$ complement.

${ }^{3}$ Kindly provided by Dr. H. J. Rapp.

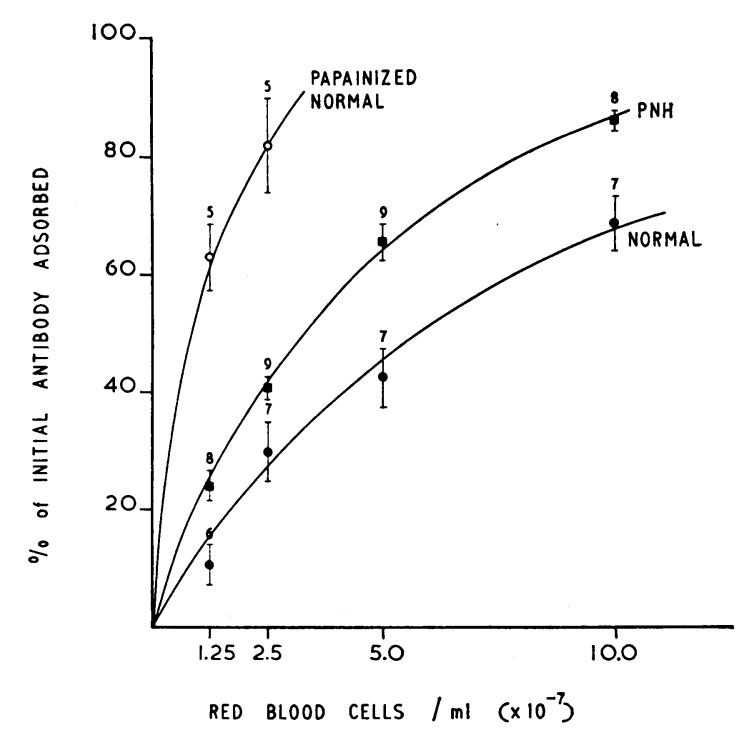

Fig. 1. The adsorption OF ANTI-I ANTIBODY BY NORMAL, PAROXYSMAL NOCTURNAL HEMOGLOBINURIA (PNH), AND PAPAINIZED NORMAL CELLS. The points represent the mean percentage of antibody adsorbed by the given number of red cells; the standard error of the mean is indicated by the brackets, and the number of determinations is indicated above the brackets. Determinations were performed on cells of five $\mathrm{PNH}$ patients and seven normal donors.

cells compared with normal cells to adsorb antibody may be calculated by determining the ratio of the number of cells of each type required to adsorb a given percentage of antibody. The ratio for $\mathrm{PNH}$ cells was 1.9 , indicating that almost twice as many normal cells as PNH cells are required to adsorb the same amount of antibody. The adsorption ratio for different patients with $\mathrm{PNH}$ was similar. The ratio for papainized normal cells was 7.9 , indicating that these cells adsorbed a great deal more antibody per cell than either normal cells or PNH cells.

The fixation of $C^{\prime} 1 a$ by antibody and cells. The results of the experiments using the $C^{\prime} 1 \mathrm{a}$ fixation and transfer test on normal, papainized normal, and PNH cells are shown in Table II. In each case the same number of cells was mixed with the same amount of antibody and $\mathrm{C}^{\prime} 1 \mathrm{a}$. Normal and PNH cells fixed the same number of $\mathrm{C}^{\prime} 1 \mathrm{a}$ molecules per cell, whereas papainized normal cells fixed about 2.5 times as much $C^{\prime} 1$ a per cell.

The fixation of complement related to antibody adsorbed. In Table III are shown the results of experiments in which the amount of $\mathrm{C}^{\prime}$ and the amount of antibody were measured before and 
TABLE II

Results of $C^{\prime} 1 a$ fixation and transfer test on normal, papainized normal, and PNH red cells with anti-I antibody*

\begin{tabular}{lccc}
\hline \hline \multirow{2}{*}{ Cells } & $\begin{array}{c}\text { No. of } \\
\text { tests }\end{array}$ & \multicolumn{2}{c}{ Molecules of C'1a fixed per cell } \\
\cline { 3 - 4 } & & Mean & SD \\
\hline Normal & 6 & 4,030 & $\pm 1,260$ \\
PNH & 3 & $4,790 \dagger$ & $\pm 1,530$ \\
Papainized & 4 & $10,430 \ddagger$ & $\pm 1,570$ \\
normal & & &
\end{tabular}

* $\mathrm{C}^{\prime} 1 \mathrm{a}=$ activated first component of complement. + Mean not significantly different from normal. $\ddagger$ Mean significantly different from normal $p<0.01$.

after the reaction of both with normal and $\mathrm{PNH}$ cells. The amount of $\mathrm{C}^{\prime}$ fixed per unit of antibody is approximately the same for both types of cells in each experiment. This indicates that the fixation of the component or components of $\mathrm{C}^{\prime}$ that limit the hemolytic reaction $\left[\mathrm{C}^{\prime} 2\right.$ or one of the $C^{\prime} 3$ components (6) $]$ is the same for both types of cells.

The rate of net formation of $E A C^{\prime}{ }_{1 a, 4,2 a}$ with functionally purified $C^{\prime} 2$. When functionally purified $\mathrm{C}^{\prime} 2$ is added to cells in the state $\mathrm{EAC}^{\prime}{ }_{1 \mathrm{~s}, 4}$, cells in the state $\mathrm{EAC}^{\prime}{ }_{1 \mathrm{a}, 4,2 \mathrm{a}}$ are formed that can be lysed by $C^{\prime}$-EDTA. The number of $\mathrm{EAC}^{\prime}{ }_{1 \mathrm{a}, 4,2 \mathrm{a}}$ at any given time after the addition of $C^{\prime} 2$ is a function of the rate of addition of $C^{\prime} 2$ and the rate of degradation of $\mathrm{EAC}^{\prime}{ }_{1 \mathrm{a}, 4,2 \mathrm{a}}$ to $\mathrm{EAC}^{\prime}{ }_{1 \mathrm{a}, 4}$. There is a time after the addition of $\mathrm{C}^{\prime} 2$, then, at which the number of $\mathrm{EAC}^{\prime}{ }_{1 \mathrm{a}, 4,2 \mathrm{a}}$ is maximal, since the rate of degradation is slower than the rate of addition. The time, $t_{\max }$, after the addition of $\mathrm{C}^{\prime} 2$ to cells in the state $\mathrm{EAC}^{\prime}{ }_{1 \mathrm{a}, 4}$ at which the greatest number of cells in the state

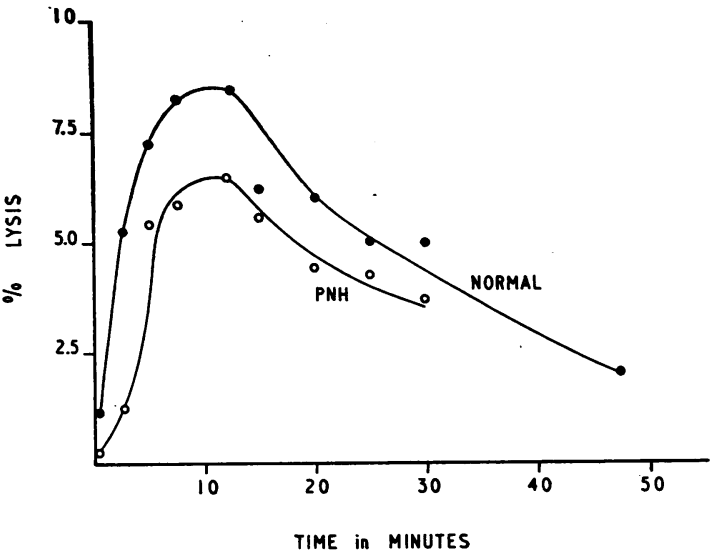

Fig. 2. THE RATE OF FORMATION AND DEgRALATION OF EAC $_{1 \Omega, 4,2 a}$ MADE BY THE ADDITION OF PURIFIED $C^{\prime} 2$ TO NORMAL AND PNH CELls IN THE STATE EAC' ${ }_{18,4}$. $C^{\prime}$. EDTA was added at specified intervals after the addition of $C^{\prime} 2$ (abscissa), and the amount of lysis after further incubation was measured (ordinate). Normal and PNH cells had been treated under identical conditions of $\mathrm{C}^{\prime}$ concentration and incubation times and temperatures in the formation of the intermediate $\mathrm{EAC}_{1 \mathrm{a}, 4}$. $\mathrm{EA}=$ sensitized red cells; subscripts denote components of complement $\left(\mathbf{C}^{\prime}\right)$ sometimes activated (a).

$\mathrm{EAC}^{\prime}{ }_{1 \mathrm{a}, 4,2 \mathrm{a}}$ were present was found to be the same for both normal and PNH cells that had been treated identically (Figure 2).

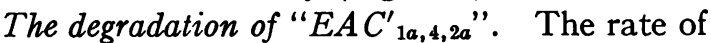
degradation of "EAC' ${ }_{1 \mathrm{a}, 4,2 \mathrm{a}}$ " made with human $\mathrm{C}^{\prime}$ and normal and PNH cells is illustrated in Figure 3. Normal cells from four donors gave a single component exponential curve with a mean $t_{1}$ of 220 minutes (range, 164 minutes to 251 minutes). The cells from three patients with $\mathrm{PNH}$ each gave two-component curves, a slow

TABLE III

The fixation of human complement related to the adsorption of anti-I antibody by normal and $P N H$ red cells

\begin{tabular}{|c|c|c|c|c|c|c|}
\hline \multirow[b]{2}{*}{ Experiment } & \multicolumn{2}{|c|}{$\begin{array}{c}\text { Incubation } \\
\text { conditions }\end{array}$} & \multirow[b]{2}{*}{$\begin{array}{l}\text { Type of } \\
\text { cells }\end{array}$} & \multirow[b]{2}{*}{$C^{\prime}$ fixed } & \multirow[b]{2}{*}{$\begin{array}{l}\text { Antibody } \\
\text { adsorbed }\end{array}$} & \multirow[b]{2}{*}{$\begin{array}{c}\mathrm{C}^{\prime} \mathrm{H}_{50} \text { fixed } \\
\mathrm{AbH} \mathrm{H}_{50} \text { adsorbed }\end{array}$} \\
\hline & Time & $\begin{array}{l}\text { Temper- } \\
\text { ature }\end{array}$ & & & & \\
\hline & hours & ${ }^{\circ} \mathrm{C}$ & & $C^{\prime} H_{50} U^{*}$ & $A b H_{s 0} U^{*}$ & \\
\hline 1 & 1 & 0 & $\begin{array}{l}\text { Normal } \\
\text { PNH }\end{array}$ & $\begin{array}{l}3.25 \\
2.45\end{array}$ & $\begin{array}{l}2,580 \\
3,190\end{array}$ & $\begin{array}{l}0.0013 \\
0.0008\end{array}$ \\
\hline 2 & 2 & 0 & $\begin{array}{l}\text { Normal } \\
\text { PNH }\end{array}$ & $\begin{array}{l}2.80 \\
3.55\end{array}$ & $\begin{array}{l}2,110 \\
2,290\end{array}$ & $\begin{array}{l}0.0013 \\
0.0017\end{array}$ \\
\hline $3 \dagger$ & 24 & 3 & $\begin{array}{l}\text { Normal } \\
\text { PNH }\end{array}$ & $\begin{array}{l}22.0 \\
16.8\end{array}$ & $\begin{array}{l}8,380 \\
8,630\end{array}$ & $\begin{array}{l}0.026 \\
0.020\end{array}$ \\
\hline $4 \dagger$ & 18 & 4 & $\begin{array}{l}\text { Normal } \\
\text { PNH }\end{array}$ & $\begin{array}{l}6.3 \\
8.0\end{array}$ & $\begin{array}{l}10,740 \\
10,474\end{array}$ & $\begin{array}{l}0.00059 \\
0.00076\end{array}$ \\
\hline
\end{tabular}

${ }^{*} \mathrm{C}^{\prime} \mathrm{H}_{50}$ and $\mathrm{AbH}_{50}=50 \%$ hemolytic units of complement and antibody.

$\dagger$ Stroma obtained by gradual osmotic lysis used instead of intact red cells. 


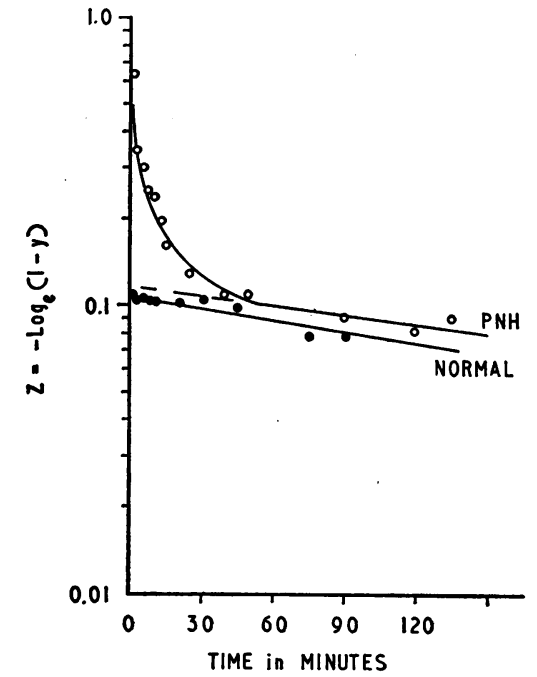

Fig. 3. The Rate of Degradation of the cellular INTERMEDIATE "EAC' ${ }_{1 \mathrm{a}, 4,2 \mathrm{a}}$ " (WITH HUMAN $\mathrm{C}^{\prime}$ ) TO EAC $_{1 \mathrm{a}, 4}$, AT $37^{\circ} \mathrm{C}$. Normal and PNH cells treated under identical conditions were used to make "EAC' ${ }_{1 \mathrm{a}, 4,2 \mathrm{a} .}$ " The presence of $C^{\prime} 3$ components on the complexes was not excluded by the preparative procedures. $y$ is the per cent lysis of sheep cells used in assay of $C^{\prime} 1$ a.

component much like that given by normal cells and a fast component with a $t_{\frac{1}{2}}$ of about 5 to 8 minutes.

When "EAC' ${ }_{1 \mathrm{a}, 4,2}$ " were made with guinea pig complement, similar results were seen: normal human cells from three donors gave a single component exponential curve with a mean $t_{\frac{1}{2}}$ of 56 minutes, whereas $\mathrm{PNH}$ cells from three patients gave a two-component curve, the slow component having a mean of 54 minutes and the fast

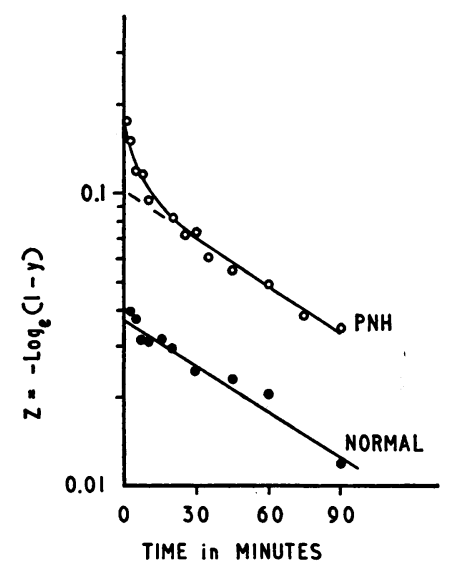

Fig. 4. The rate of DEgradation of the cellular INTERMEDIATE "EAC' ${ }_{1 \mathrm{a}, 4,2 \mathrm{~g}}$ " (WITH GUINEA PIG C') TO EAC $_{1 \mathrm{a}, 4}$ AT $37^{\circ} \mathrm{C}$. See legend to Figure 3 for details.

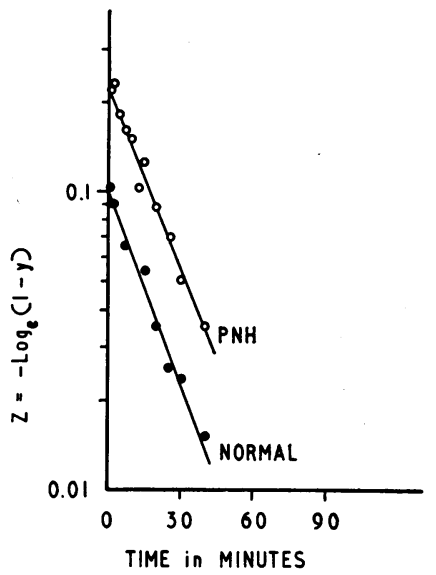

Fig. 5. THE RATE OF DEgradation of the cellular INTERMEDIATE "EAC' ${ }_{1 \mathrm{a}, 4,2 \mathrm{a}}$ " (WITH GUINEA PIG C') TO $\mathrm{EAC}_{1 \mathrm{a}, 4}^{\prime} \mathrm{AT} 37^{\circ} \mathrm{C}$. Details are as in Figures 3 and 4 except that the presence of $\mathrm{C}^{\prime} 3$ components in the cellular intermediates was excluded by the preparation procedures:

component having a $t_{3}$ of about 5 minutes (Figure 4).

When the presence of $\mathrm{C}^{\prime} 3$ components in the cellular intermediates was excluded by preparing $\mathrm{EAC}_{1 \mathrm{a}, 4,2 \mathrm{a}}^{\prime}$ from $\mathrm{EAC}_{1 \mathrm{a}, 4}^{\prime}+$ purified $\mathrm{C}^{\prime} 2$, $\mathrm{EAC}^{\prime}{ }_{1 \mathrm{a}, 4,2 \mathrm{a}}$ made from normal and $\mathrm{PNH}$ cells and guinea pig $\mathrm{C}^{\prime}$ components were found to have the same rate of degradation, corresponding to that of the rapidly decaying component seen with PNH cells (Figure 5). This strongly suggests that the slow rate of degradation seen with normal cells and with part of the PNH cells was in fact due to the presence of cells in the state $\mathrm{EAC}^{\prime}{ }_{1 \mathrm{a}, 4,2 \mathrm{a}, 3 \text { componen ts. }}{ }^{4}$

\section{Discussion}

In a previous paper (1), we have shown that the lysis of a given percentage of sensitive $\mathrm{PNH}$ cells sensitized with large amounts of antibody required a mean of one-twenty-fifth the amount of complement needed to lyse the same number of normal cells. However, the experiments reported in that paper did not indicate whether unusual ability of these cells to utilize antibody or unusual sensitivity to complement is responsible for the increased lysis.

An unusual ability of $\mathrm{PNH}$ cells to utilize antibody ought to be demonstrable either as an increased amount of antibody adsorbed into the

4. This interpretation was suggested by Dr. H. J. Rapp. 
cells compared to normal cells or an increased ability of the antigen-antibody combination to initiate complement reactions, i.e., to fix $\mathrm{C}^{\prime} 1$. From the adsorption experiments, it appears that somewhat more antibody is removed from solution by a given number of $\mathrm{PNH}$ cells than normal cells. This would suggest that $\mathrm{PNH}$ cells have somewhat increased affinity for antibody under these conditions. Costea, Yakulis, and Heller have also demonstrated a somewhat greater uptake of ${ }^{131}$-labeled cold-reacting antibody from rabbits on PNH cells (14). However, this apparent small increase in affinity for antibody binding does not result in an increase in fixation of $\mathrm{C}^{\prime} 1 \mathrm{a}$. Hence normal and PNH cells do not appear to differ significantly in their ability to fix $C^{\prime} 1 \mathrm{a}$ and thus initiate $C^{\prime}$ reactions.

On the other hand, normal cells that have been papainized adsorb larger amounts of antibody from solution than normal or PNH cells. These cells fix two and one-half times as much $\mathrm{C}^{\prime} 1 \mathrm{a}$ under the same conditions as normal or $\mathrm{PNH}$ cells. This markedly increased affinity for antibody may well explain the twofold increase in complement lysis sensitivity seen with papainized cells (see Table I). It is evident, however, that differences in antibody affinity or ability to initiate complement reactions cannot explain the 25 -fold difference in $\mathrm{C}^{\prime}$ lysis sensitivity between normal and sensitive $\mathrm{PNH}$ cells. Hence the reason for this difference must be sought in differences in the effectiveness of complement once the sequence of reactions has been begun.

The early reactions of $C^{\prime}$ are not only qualitatively the same on the two types of cells but quantitatively the same as well. This means that the same number of $C^{\prime}$ reactions are begun on normal and PNH cells when the amount of antibody and $\mathrm{C}^{\prime}$ in the reaction mixture is the same. Hence differences in effectiveness of $\mathrm{C}^{\prime}$ must occur late in the complement sequence. Since the same amount of complement (as measured by the titration with sensitized sheep cells) is fixed by normal and $\mathrm{PNH}$ cells, the complement sequence must be quantitatively the same on these two types of cells, at least through the step in which $C^{\prime} 2$ is added. This is because the titer of complement in whole serum is dependent upon the titer of the limiting component or upon limiting reactions in the sequence of complement reactions; in human serum, the limiting component is probably $\mathrm{C}^{\prime} 2$ or one of the $\mathrm{C}^{\prime} 3$ components (6). Therefore, the fixation of the limiting component and all components that react before it (i.e., at least $C^{\prime} 1$ and $C^{\prime} 4$ ) must be the same for normal and PNH cells. This is confirmed by the studies with addition of $\mathrm{C}^{\prime} 2$. As outlined above, $t_{\max }$, the time after the addition of $C^{\prime} 2$ to cells in the state $\mathrm{EAC}^{\prime}{ }_{1 \mathrm{a}, 4}$ at which the greatest number of cells are in the state $\mathrm{EAC}^{\prime}{ }_{1,4,2 \mathrm{a}}$, is related only to the number of sites in the state $\mathrm{SAC}^{\prime}{ }_{1 \mathrm{a}, 4}$ per cell. Therefore, since the $t_{\max }$ is the same for normal and PNH cells, the number of $\mathrm{SAC}_{1 \mathrm{a}, 4}^{\prime}$ per cell presumably is the same.

The complex of steps involving $\mathrm{C}^{\prime} 2$ that follows the addition of $C^{\prime} 1$ and $C^{\prime} 4$ also appears to be the same for normal and $\mathrm{PNH}$ cells. If $\mathrm{C}^{\prime} 2$ is the limiting component or if the limiting component follows the addition of $\mathrm{C}^{\prime} 2$, then the amount of $\mathrm{C}^{\prime} 2$ fixed must be the same for normal and $\mathrm{PNH}$ cells treated in the same way. We originally felt that greater efficiency of $\mathrm{C}^{\prime}$ in lysing $\mathrm{PNH}$ cells might reside in a slower rate of degradation of $\operatorname{EAC}^{\prime}{ }_{1,4,2 a}$ to $\operatorname{EAC}^{\prime}{ }_{1 \mathrm{a}, 4}$. However, when $\mathrm{EAC}^{\prime}{ }_{1 \mathrm{a}, 4,2 \mathrm{a}}$ is made with functionally pure $\mathrm{C}^{\prime} 2$ in order to exclude the presence of $\mathrm{C}^{\prime} 3$ components, the rate of degradation of this intermediate appears to be the same for normal and $\mathrm{PNH}$ cells. Therefore, the difference between these cells in sensitivity to lysis by $\mathrm{C}^{\prime}$ must lie in the final steps of the $\mathrm{C}^{\prime}$ sequence, those involving $\mathrm{C}^{\prime} 3$ and the $\mathrm{E}^{*}$ state.

We have little information about the steps involving $\mathrm{C}^{\prime} 3$ components on normal and $\mathrm{PNH}$ cells, partly because these steps are themselves only partially understood. Recent work by Yachnin suggests that partially purified $\mathrm{C}^{\prime} 3$ components are more effective in lysing $\mathrm{PNH}$ cells than normal cells (15). This was interpreted to mean that more of the component was adsorbed to the PNH cells than to the normal cell. However, the present work would suggest that if the data are correct, a likely interpretation is that the same amount of $\mathrm{C}^{\prime} 3$ components is adsorbed on normal and $\mathrm{PNH}$ cells but that PNH cells lyse because of their remarkable sensitivity to the action of the last components of the complement sequence.

The final steps before the lysis of the cells, that is, the formation of membrane defects, are 
discussed at length in the third paper of this series (16). Pertinent to the present discussion, though, are the findings that the defects formed in the red cell membrane by the action of $\mathrm{C}^{\prime}$ are the same for normal and PNH cells.

On the basis of these studies, we should like to suggest that the difference between normal and $\mathrm{PNH}$ cells in apparent efficiency of $\mathrm{C}^{\prime}$ possibly results from differences in the ease with which the membrane defect (or "hole") responsible for lysis is made. Thus, for the same number of initiated complement reactions, the chances of a membrane defect being formed are many times greater for the sensitive $\mathrm{PNH}$ cell than for a normal cell.

\section{Summary}

1. The relative roles of antibody and complement in the increased sensitivity of paroxysmal nocturnal hemoglobinuria (PNH) cells to complement lysis have been investigated.

2. The amount of anti-I antibody adsorbed by $\mathrm{PNH}$ red cells is somewhat greater than that adsorbed by normal cells, but the amount of the activated first component of complement $\left(\mathrm{C}^{\prime} 1 \mathrm{a}\right)$ fixed by equally sensitized normal and $\mathrm{PNH}$ red cells is equal. This suggests that these cells do not differ in the efficiency with which $C^{\prime}$ la is bound.

3. Papainized normal cells adsorb much greater amounts of antibody and fix at least twice the amount of $C^{\prime} l a$ as normal cells. This probably explains at least in part the somewhat greater sensitivity of these cells to immune lysis.

4. Investigation of several steps of the sequence of reactions involving components of complement indicates that, under the same conditions of antibody and complement concentration and incubation, normal and $\mathrm{PNH}$ cells have the same number of sites containing $C^{\prime} 1$ and $\mathrm{C}^{\prime} 4\left(\mathrm{SAC}_{1 \mathrm{a}, 4}^{\prime}\right)$ and fix the same amount of the limiting component of complement $\left(\mathrm{C}^{\prime} 2\right.$ or one of the $C^{\prime} 3$ components). The rate of degradation of sensitized red cells bearing complement components $1 \mathrm{a}, 4$, and $2 \mathrm{a}\left(\mathrm{EAC}^{\prime}{ }_{1 \mathrm{a}, 4,2 \mathrm{a}}\right)$ was the same for the two types of cells. Since the complement steps through the $\mathrm{C}^{\prime} 2$ reactions are quantitatively the same for normal and $\mathrm{PNH}$ cells, the increased efficiency of complement in bringing about the lysis of PNH cells is due to differences in the last steps of the sequence of complement reactions, that is, in those steps involving $\mathrm{C}^{\prime} 3$ components and damage to the cellular membrane.

\section{Acknowledgments}

We wish to thank Drs. H. J. Rapp and Tibor Borsos, Immunochemistry Section, Immunology Branch, National Cancer Institute, for their help in providing purified components of complement and principles of complement component investigation.

\section{References}

1. Rosse, W. F., and J. V. Dacie. Immune lysis of normal human and paroxysmal nocturnal hemoglobinuria $(\mathrm{PNH})$ red blood cells $\mathrm{I}$. The sensitivity of $\mathrm{PNH}$ red cells to lysis by complement and specific antibody. J. clin. Invest. 1966, 45, 736.

2. Lewis, S. M., J. V. Dacie, and D. Tills. Comparison of the sensitivity to agglutination and haemolysis by a high-titre cold antibody of the erythrocytes of normal subjects and of patients with a variety of blood diseases including paroxysmal nocturnal haemoglobinuria. Brit. J. Haemat. 1961, 7, 64.

3. Mayer, M. M. Complement and complement fixation in Experimental Immunochemistry, 2nd ed., E. Kabat and M. M. Mayer, Eds. Springfield, Ill., Charles C Thomas, 1961, p. 133.

4. Borsos, T., H. J. Rapp, and U. L. Walz. Action of the first component of complement. Activation of $\mathrm{C}^{\prime} 1$ to $\mathrm{C}^{\prime} 1 \mathrm{a}$ in the hemolytic system. J. Immunol. 1964, 92, 108.

5. Borsos, T., H. J. Rapp, and M. M. Mayer. Studies on the second component of complement. II. The nature of the decay of $\mathrm{EAC}^{\prime} 1,4,2$. J. Immunol. 1961, 87, 326.

6. Rapp, H. J. The nature of complement and the design of a complement fixation test in Immunological Methods, J. F. Ackroyd, Ed. Oxford, Blackwell, 1964, p. 1.

7. Frank, M. M., H. J. Rapp, and T. Borsos. Studies on the terminal steps of immune hemolysis. I. Inhibition by trisodium ethylenediamine-tetraacetate (EDTA). J. Immunol. 1964, 93, 409.

8. Frank, M. M., H. J. Rapp, and T. Borsos. Studies on the terminal steps of immune hemolysis. II. Resolution of the $E^{*}$ transformation reaction into multiple steps. J. Immunol. 1965, 94, 295.

9. Rapp, H. J., and T. Borsos. Effects of low ionic strength on immune hemolysis. J. Immunol. 1963, 91, 826.

10. Borsos, T., and H. J. Rapp. Hemolysin titration based on fixation of the activated first component of complement: evidence that one molecule of hemolysin suffices to sensitize an erythrocyte. J. Immunol. 1965, 95, 559.

11. Rosse, W. F., T. Borsos, and H. J. Rapp. The fixa- 
tion of the first component of complement by cold agglutinin antibodies. In preparation.

12. Borsos, T., and H. J. Rapp. Chromatographic separation of the first component of complement and its assay on a molecular basis. J. Immunol. 1963, 91, 851.

13. Borsos, T., H. J. Rapp, and M. M. Mayer. Studies on the second component of complement. I. The reaction between $\mathrm{EAC}^{\prime} 1,4$ and $\mathrm{C}^{\prime} 2$ : evidence on the single site mechanism of immune hemolysis and determination of $\mathrm{C}^{\prime} 2$ on a molecular basis. J. Immunol. 1961, 87, 310.
14. Costea, N., V. Yakulis, and P. Heller. Experimental production of cold agglutinins in rabbits. Blood 1965, 26, 323.

15. Yachnin, S. The hemolysis of red cells from patients with paroxysmal nocturnal hemoglobinuria by partially purified subcomponents of the third complement component. J. clin. Invest. 1965, 44, 1534.

16. Rosse, W. F., R. Dourmashkin, and J. H. Humphrey. Immune lysis of normal human and paroxysmal nocturnal hemoglobinuria $(\mathrm{PNH})$ red blood cells. III. The membrane defects caused by complement. J. exp. Med. In press. 